\title{
PENGHAYATAN SELIBAT IMAM \\ SEBAGAI KESAKSIAN HIDUP DI ZAMAN SEKARANG
}

\author{
Yohanes Hario Kristo Wibowo
}

\begin{abstract}
Abstrak:
Celibacy as a living testimony calls for a re-interpretation on its meaning. Re-engagement on celibacy is sought by reflecting deeply and discovering the richness of its meaning and value, especially through the Scriptures and Church Documents. The attempt to interpret the meaning of celibacy aims to discover the privilege of that choice of life. That privilege is necessary for celibacy to be an inspiring and truly relevant life choice in today's world. Celibacy will increasingly become a living witness for the people today, when is lived with joy by the priests and religious with the support of the faithful and the grace of God. Thus, celibacy becomes a viable choice of life to be appreciated and championed. How to love, how to serve, and way of life are three points of re-interpretation of the meaning of celibacy as a testimony. These three ways are an approach that needs to be endeavored and lived continuously so that celibacy becomes a meaningful witness of life for the Church and does not close the possibility of being a testimony to the people around them.
\end{abstract}

\section{Kata-kata Kunci:}

selibat, imamat, reinterpretasi, kultur, kesaksian, pelayanan

\section{LATAR BELAKANG}

Hidup selibat merupakan suatu pilihan hidup yang tidak mudah untuk dijalani dalam situasi dunia saat ini. ${ }^{1}$ Pernyataan tersebut diperkuat dengan terungkapnya kasus seksual yang terjadi pada beberapa imam di Amerika Serikat pada beberapa tahun silam. Ditemukan data bahwa antara kurun waktu 2002-2003, dari 46.000 imam di Amerika, ada 325 imam yang telah diberhentikan atau dibebastugaskan dari imamat, karena kasus pedophilia. Antara tahun 1995-2003, sebanyak 4.392 imam telah dituduh oleh 10.667 orang terkait kasus seksual. Kasus yang paling banyak terjadi adalah di Keuskupan Boston. ${ }^{2}$
Terkait dengan terungkapnya kasus tersebut, muncul suatu tanggapan yang dimuat dalam salah satu edisi majalah Hidup, dicantumkan sebuah judul: "Selibat Berat atau Berkat"3. Adanya kasus yang melibatkan beberapa imam di Amerika Serikat, tidak menutup kemungkinan bahwa hal yang serupa bisa saja terjadi di Indonesia. Hanya saja, belum ada data pasti yang menunjukkan terjadinya hal tersebut. Fenomena tersebut dapat menjadi pembelajaran tersendiri bagi para imam di Indonesia, terutama dalam melaksanakan hidup selibatnya.

Dengan mencermati kembali judul majalah tersebut: "Selibat Berat atau Berkat", nampaknya ada upaya memper- 
tanyakan kembali pemaknaan hidup selibat pada masa kini. Idealnya, selibat menjadi lambang dan dorongan cinta kasih dalam pelayanan kegembalaan serta sumber istimewa bagi kesuburan rohani di dunia ini. ${ }^{4}$ Akan tetapi, dengan terjadinya kasus seksual tersebut, hidup selibat bisa saja justru dianggap sebagai status atau label palsu dan sebuah pelecehan religius. ${ }^{5}$ Penyebabnya bisa jadi karena pemaknaan yang keliru atas pilihan hidup selibat atau hanya dimaknai sebagai suatu elemen wajib dalam hidup Imamat. ${ }^{6}$

Pada situasi saat ini, upaya para imam menghayati hidup selibat dihadapkan dengan beberapa tantangan zaman. Dalam Direktorium Tentang Pelayanan dan Hidup para Imam dinyatakan bahwa:

"Iklim budaya dewasa ini sering dipengaruhi oleh visi manusia yang tidak memiliki nilai-nilai dan tidak mampu memberi makna yang lengkap, positif, dan membebaskan kepada seksualitas manusiawi. Dalam iklim budaya itu seringkali dipertanyakan nilai dan makna selibat imam."7

Pilihan hidup untuk "tidak kawin" bisa dipandang tidak lazim dalam situasi zaman yang cenderung dipengaruhi oleh pandangan bahwa seksualitas merupakan sarana rekreasi semata. ${ }^{8}$ Kecenderungan hedonisme zaman sekarang menempatkan seksualitas sebagai kesenangan belaka, sehingga mengabaikan aspek kerohanian di dalamnya. ${ }^{9}$ Perkembangan ilmu pengetahuan dan teknologi bisa turut berperan membentuk cara pandang mengenai seksualitas sebagai sarana hiburan semata. Dengan memanfaatkan internet, orang dengan mudah mengakses konten pornografi. Melalui kecanggihan sarana telekomunikasi, seorang imam dapat tergoda menjalin relasi tidak sehat dengan seorang perempuan, sehingga membahayakan komitmen untuk hidup selibat. Hal-hal semacam itu perlu diwaspadai oleh para imam dalam menghayati hidup selibatnya pada zaman sekarang.

Selain itu, ada pula pandangan tradisional dalam beberapa aspek kultur di Indonesia yang melihat selibat sebagai pilihan hidup yang "aneh". Ada pula anggapan bahwa hidup selibat itu melawan kodrat dan tidak manusiawi, karena dinilai tidak dapat mencapai kematangan dan keseimbangan pribadi. ${ }^{10}$

Berhadapan dengan beberapa situasi semacam itu, nilai dan makna hidup selibat imam perlu diartikulasikan kembali dengan cara mereinterpretasi nilai dan makna hidup selibat. Harapannya, selibat dapat dipahami sebagai pilihan hidup yang berharga, menginspirasi dan menjadi daya tarik bagi umat Kristiani, khususnya kaum muda. Dengan demikian, hidup selibat bukanlah pilihan hidup yang dianggap tidak relevan, tetapi tetap memberikan suatu kontribusi yang berarti dalam kehidupan masa kini.

\section{PENGERTIAN HIDUP SELIBAT IMAM}

Istilah "selibat" secara etimologis berasal dari bahasa Latin, caelebs artinya tunggal, orang yang tidak menikah ${ }^{11}$ atau caelibatus artinya hidup tidak menikah. ${ }^{12}$ Dalam Katekismus Gereja Katolik, gagasan mengenai selibat secara langsung merujuk para pelayan tertahbis untuk Gereja Latin. ${ }^{13}$ Dalam Gereja Katolik Latin, semua pejabat tertahbisnya, termasuk para imam merupakan para laki-laki beriman yang memiliki kehendak dan kesediaan untuk mengungkapkan dan melaksanakan suatu komitmen pribadi, yakni hidup tidak menikah demi Kerajaan Surga selama seumur hidupnya. ${ }^{14}$

Komitmen pribadi tersebut disertai dengan kejujuran ${ }^{15}$ dan keyakinan diri bahwa panggilan hidup yang dipilih merupakan jalan hidup yang berharga dan layak untuk diperjuangkan. Oleh karena itu, seorang calon imam hendaknya memilih untuk hidup selibat disertai dengan kesadaran, pertimbangan yang matang, kerelaan hati, dan tanpa adanya paksaan dari pihak luar, termasuk tidak dipengaruhi oleh situasi di luar dirinya. ${ }^{16}$

Di sisi lain, dalam Hukum Gereja, selibat dibicarakan terkait dengan suatu kewajiban, sebagaimana dinyatakan dalam Kitab $\mathrm{Hu}$ kum Kanonik:

"Para klerikus terikat kewajiban untuk memelihara tarak sempurna dan selamanya demi Kerajaan surga, dan karena itu terikat selibat yang merupakan anugerah istimewa Allah; dengan itu para pelayan 
suci dapat lebih mudah bersatu dengan Kristus dengan hati tak terbagi dan membaktikan diri lebih bebas untuk pelayanan kepada Allah dan kepada manusia."17

Tegangan antara pilihan bebas dan kewajiban, dapat dijembatani dengan menyadari kembali komitmen pribadi untuk memilih hidup selibat. Seseorang yang berkomitmen secara bebas, sadar, matang, dan bertanggung jawab akan memaknai hidup selibat sebagai kewajiban yang membebaskan. Ia dapat lebih bebas untuk bersatu dengan Kristus dan menjadi pribadi yang mudah bergerak, mudah untuk didekati, dan dimintai pertolongan oleh umat. $^{18}$

Pelaksanaan komitmen untuk hidup selibat merupakan sebuah kesaksian, terutama dalam situasi zaman yang cenderung dipengaruhi oleh pandangan bahwa seksualitas sekadar sebagai sarana rekreasi. ${ }^{19}$ Dalam kaitannya dengan seksualitas, hidup selibat memberikan kesaksian tentang kemampuan untuk mengintegrasikan dorongan seksual. Seorang imam merupakan pribadi yang utuh, termasuk adanya dorongan seksual dalam dirinya. Dorongan seksual tersebut diaktualisasikan dalam karya pelayanan dan pengabdian kepada sesama.

Pilihan hidup selibat juga menjadi kesaksian untuk bersedia mendedikasikan diri untuk pelayanan dengan hati tak terbagi. ${ }^{20}$ Hidup selibat mengandung suatu keterbukaan untuk melayani kebutuhan Gereja universal, termasuk kebutuhan masyarakat. Selibat tidak menjadikan seorang imam menutup diri atas kebutuhan orang lain, tetapi justru memampukan dirinya untuk terbuka kepada realitas dan kebutuhan di luar dirinya. ${ }^{21}$ Dengan demikian, hidup selibat merupakan pilihan hidup yang tepat untuk para imam. ${ }^{22}$

A.W. Richard Sipe memahami selibat sebagai pilihan hidup yang dinamis dengan didasarkan pada kejujuran diri dan diungkapkan secara publik; komitmen untuk hidup tanpa pemenuhan seksual (sebagaimana dalam hidup perkawinan) yang disertai dengan kapasitas untuk mengintegrasikan dorongan seksual; upaya tersebut bertujuan untuk melayani sesama secara produktif dengan didasarkan pada motif spiritual. ${ }^{23}$ Selibat merupakan pilihan hidup yang layak untuk diperjuangkan, baik demi pelayanan kepada sesama, maupun demi Kerajaan Allah. Perwujudan atas hidup selibat inilah yang menjadi suatu pewartaan dan tawaran bagi kehidupan masyarakat masa kini.

\section{BEBERAPA ASPEK TEOLOGIS HIDUP SELIBAT}

Gagasan mengenai hidup selibat imam akan semakin lengkap dengan menganalisis beberapa aspek teologis yang terdapat dalam hidup selibat, yakni aspek kristologis, ekklesiologis, eskatologis, karismatis, dan profetis.

\section{Aspek Kristologis}

Hidup selibat merupakan suatu bentuk pilihan hidup yang dianjurkan oleh Kristus. ${ }^{24}$ Dalam hidup-Nya sebagai manusia, Kristus menjaga dan memelihara kemurnian diri-Nya dengan melaksanakan hidup selibat. ${ }^{25}$ Seturut dengan teladan Kristus, para imam melaksanakan hidup selibat, memilih untuk tidak kawin demi Kerajaan Allah.

Kristus merupakan Imam Abadi dan model imam yang ideal. ${ }^{26}$ Imamat Kristiani mengambil bagian dalam Imamat Kristus. Dengan mengambil bagian dalam Imamat Kristus, para imam turut serta dalam karya pelayanan Kristus bagi manusia. Kristus telah menyatakan bahwa: "Anak Manusia datang bukan untuk dilayani, melainkan untuk melayani dan untuk memberikan nyawa-Nya menjadi tebusan bagi banyak orang" (Mat. 20:28). Pelayanan Kristus di dunia diwujudkan secara total dengan memberikan nyawa-Nya sebagai tebusan bagi banyak orang. Peristiwa Paskah merupakan peristiwa keselamatan bagi manusia yang percaya kepada-Nya dan sekaligus menjadi puncak karya pelayanan Kristus bagi banyak orang.

Dalam tugas perutusan-Nya, Kristus mendedikasikan seluruh hidupnya demi pelayanan kepada Allah dan manusia. Pemberian diri yang total kepada Allah dan untuk keselamatan manusia tersebut diwujudkan-Nya melalui hidup selibat. Pelayanan 
Kristus untuk keselamatan manusia itu dihadirkan kembali melalui karya pelayanan seorang imam di dalam dunia. ${ }^{27}$ Dengan hidup selibat yang dihayatinya, seorang imam dapat secara lebih total memberikan diri dalam karya pelayanannya. Seorang imam dipanggil untuk memberikan dirinya secara total kepada Allah dengan hati yang tak terbagi. Ia dipanggil untuk mengorbankan dirinya bagi sesama, seperti yang telah diteladankan oleh Kristus. ${ }^{28}$

\section{Aspek Ekklesiologis}

Kristus secara total mempersembahkan diri-Nya untuk kemuliaan, kesucian, dan kekudusan Gereja. ${ }^{29}$ Relasi yang erat antara Kristus dan Gereja digambarkan dengan ungkapan bahwa Gereja ialah mempelai Kristus. "Selaku Mempelai Yesus Kristus, Gereja ingin dikasihi oleh imam secara menyeluruh dan eksklusif, seperti Yesus Kristus, Kepala, dan Mempelainya, mengasihinya."30

Seorang imam berperan seperti Kristus sebagai Imam Abadi yang telah mencintai Gereja sebagai mempelai-Nya. Hidup selibat menunjukkan suatu pengabdian yang total seorang imam kepada Gereja, sebagaimana Kristus memberikan diri-Nya untuk kehidupan Gereja. Selibat imam merupakan suatu wujud pemberian dan pengorbanan diri seorang imam dalam relasi cinta Kristus kepada Gereja. ${ }^{31}$ Seorang imam memberikan diri seutuhnya untuk melayani Tuhan dan Tubuh Mistik-Nya yakni Gereja secara lebih bebas. ${ }^{32}$ Ia dapat menyuarakan kepentingan dan kebutuhan Gereja baik dalam karya pelayanan pastoralnya maupun dalam doa-doanya untuk kepentingan Gereja. ${ }^{33}$ Secara khusus dalam Perayaan Ekaristi, seorang imam bertindak in persona Christi. ${ }^{34}$ Dalam perayaan Ekaristi Kristus merupakan imam, altar, dan korban. Melalui hidup selibatnya seorang imam dapat bersatu dengan Kristus secara lebih akrab dan menyeluruh. Bersama dengan Kristus, seorang imam mempersembahkan diri dan mengurbankan seluruh hidupnya bagi keselamatan Gereja. ${ }^{35}$

Hidup selibat juga turut mendukung karya pelayanan pastoral seorang imam. Ia dapat memfokuskan pikiran, mental, dan afeksinya untuk melayani kebutuhan Gereja. $^{36}$ Seorang imam dapat menjadi pribadi yang bebas dan fleksibel untuk menanggapi berbagai kebutuhan pastoral. ${ }^{37}$ Menjadi pribadi yang bebas berarti bahwa seorang dapat dapat memberikan diri seutuhnya untuk melayani Gereja. Perhatian hidupnya tidak terbagi-bagi sebagaimana dalam hidup berkeluarga, yakni memenuhi kebutuhan rumah tangga, termasuk membahagiakan istri dan anakanak. Sebagaimana dikatakan oleh Paulus:

"Orang yang tidak beristri memusatkan
perhatiannya pada perkara Tuhan, bagai-
mana Tuhan berkenan kepadanya. Orang
yang beristeri memusatkan perhatiannya
pada perkara duniawi, bagaimana ia dapat
menyenangkan istrinya, dan dengan de-
mikian perhatiannya terbagi-bagi" (1 Kor.
7:33-34).

Menjadi pribadi yang fleksibel berarti menjadi pribadi yang siap sedia dalam menjalani perutusannya. Seorang imam tidak terikat kewajiban dan tanggung jawab seperti seorang kepala keluarga yang harus selalu menjaga dan memelihara keluarganya. Seorang imam dapat memusatkan perhatiannya sepenuhnya pada karya pelayanan dalam hidup menggereja. Dengan demikian, seorang imam dapat dengan lebih baik menunaikan pelayanannya kepada umat yang dipercayakan Allah kepadanya. ${ }^{38}$

\section{Aspek Eskatologis}

Nilai eskatologis hidup selibat terkait dengan Kerajaan Allah. Hidup selibat yang menandakan kenyataan eskatologis merupakan suatu kesaksian radikal karena tidak semua orang dapat memahami pilihan untuk hidup tidak kawin demi Kerajaan Surga. ${ }^{39}$ Kehidupan selibat seorang imam merupakan suatu antisipasi atas situasi kehidupan setelah kebangkitan, yakni kehidupan yang tidak kawin dan dikawinkan. ${ }^{40}$

Hidup selibat seorang imam menghadirkan kehidupan yang akan datang tersebut di dunia ini, yakni Kerajaan Allah dalam iman dan cinta kasih. ${ }^{41}$ Upaya untuk menghadirkan Kerajaan Allah diwujudkan dalam pengabdian diri seorang imam untuk melaksanakan kehendak Allah melalui dirinya. Kehendak Allah begitu menguasai 
dirinya untuk mempersembahkan diri kepada Allah dan melayani sesamanya. Seorang imam mengorbankan keinginannya sebagai manusia dan memilih untuk hidup selibat, sehingga ia semakin terarah kepada persatuan dengan Allah. Seorang imam tinggal dan bersatu dengan Allah serta mendedikasikan dirinya pada kehendak Allah. Pengabdian diri tersebut secara lebih total dan bebas dapat dilakukan melalui hidup selibat.

Gagasan selibat sebagai suatu antisipasi akan situasi kebangkitan, dapat pula dimaknai sebagai suatu kesaksian akan tujuan akhir peziarahan umat Allah, yakni Kerajaan Allah. Gambaran tentang Kerajaan Allah itu dilukiskan dengan situasi ketika anak-anak Allah memandang Kristus duduk di sisi kanan Allah dalam kemuliaan-Nya. ${ }^{42}$ Gambaran tersebut dihadirkan melalui pribadi imam yang selibat. Ia mempersembahkan dirinya sebagaimana Kristus hadir di dunia untuk melaksanakan kehendak Bapa-Nya demi keselamatan umat manusia. Dalam kehadiran-Nya sebagai manusia, Kristus taat kepada kehendak Bapa, sehingga Kristus pun dipermuliakan oleh Bapa. ${ }^{43}$ Para imam meneladan pribadi Kristus dan mengemban tugas Kristus yang telah hadir dalam dunia ini. Dalam upaya meneladan pribadi Kristus dan turut serta dalam karya penyelamatan Kristus, para imam dapat mengharapkan bahwa kelak diperkenankan memperoleh kemuliaan bersama dengan Kristus.

\section{Aspek Kharismatis}

Selibat adalah kharisma dari Allah yang merupakan anugerah atau pemberian kepada manusia. Allah memanggil beberapa orang untuk memilih dan menjalani hidup selibat. $^{44}$ Seorang imam dipanggil Allah untuk menerima karunia kemurnian dalam hidup selibat selama hidupnya. ${ }^{45}$ Pribadi yang merasakan panggilan dari Allah perlu menanggapinya dengan sadar, bebas, dan bertanggung jawab. Ia dapat menggunakan akal budi, kehendak, dan kebebasannya untuk menerima atau menolak karunia tersebut. ${ }^{46}$ Dalam upaya menanggapi karunia tersebut dibutuhkan proses discernment (pertimbangan rohani), mempertimbangkan kapasitas dirinya untuk dapat menjalani pilihan hidup serta mencermati motivasi yang menggerakkannya untuk memilih hidup selibat. ${ }^{47}$

Selibat sebagai kharisma yang diterima dari Allah ditujukan pada karya pelayanan Gereja. Paulus pernah mengatakan bahwa setiap pribadi memiliki kharisma masingmasing untuk melayani Gereja. ${ }^{48}$ Kharisma tersebut diterima dan dihayati sebagai komit-men untuk memberikan dirinya secara total bagi kebutuhan Gereja. Dengan kharisma yang diterimanya, seorang imam merupakan pribadi yang siap sedia untuk melaksanakan pelayanan sakramental untuk keselamatan Gereja. ${ }^{49}$

Selibat sebagai kharisma tidak dapat diperoleh dengan hanya mengandalkan upaya pribadi, bukan pula karena sekadar diwajibkan atau dipaksakan. ${ }^{50}$ Hidup selibat bukan merupakan prestasi, dan bukan pula suatu harga yang harus dibayar untuk dapat ditahbiskan menjadi seorang imam. ${ }^{51}$ Akan tetapi, merupakan kharisma yang diterimanya melalui karunia Roh Kudus. ${ }^{52}$ Karunia dari Allah mengandaikan kebebasan pribadi, disertai dengan komitmen untuk menghayati karunia tersebut. Rahmat untuk hidup selibat dimohonkan juga oleh Gereja yang mengharapkan agar para imam dapat melaksanakan hidup selibatnya dengan setia. $^{53}$

\section{Aspek Profetis}

Selibat imam mempunyai makna kenabian bagi dunia masa kini. ${ }^{54}$ Pilihan hidup untuk "tidak kawin" bisa dipandang sebagai pilihan hidup yang tidak lazim dalam situasi zaman yang cenderung dipengaruhi oleh pandangan bahwa seksualitas merupakan sarana rekreasi semata. ${ }^{55}$ Terkait dengan seksualitas, hidup selibat bisa dipandang sebagai pilihan hidup yang secara biologis melawan kodrat. ${ }^{56}$ Secara biologis, seorang laki-laki yang memilih untuk hidup selibat tidak mengaktualisasikan dorongan seksual dengan melakukan hubungan seksual. ${ }^{57}$ Kekuatan yang diperoleh para imam untuk dapat menjalani hidup selibat hanya dapat diusahakan melalui kegiatan yang bersifat spiritual. ${ }^{58}$

Pengolahan hidup rohani merupakan upaya spiritual untuk menjaga hidup selibat- 
nya, termasuk dengan berdevosi kepada Santa Perawan Maria. ${ }^{59}$ Santa Perawan Maria merupakan figur yang patut untuk diteladani dalam menghayati hidup selibat. Ia mempersembahkan seluruh hidupnya, termasuk daya seksualitasnya dalam pengabdian kepada Allah. ${ }^{60}$ Persembahannya yang total kepada kehendak Allah dinyatakan dalam tanggapannya menerima kabar gembira dari malaikat Gabriel, "Sesungguhnya aku ini hamba Tuhan, jadilah padaku menurut perkataanmu itu"(Luk.1:38). Maria merupakan teladan pribadi yang dibimbing oleh Roh Kudus untuk membaktikan diri sepenuhnya untuk ikut serta dalam misteri penyelamatan manusia. ${ }^{61} \mathrm{De}-$ ngan menimba kekuatan spiritual tersebut, seorang imam dimampukan menjalani kehidupan yang melampaui kodrat, suatu bentuk kehidupan yang mengarah pada sifat adikodrati. $^{62}$

Aspek profetis hidup selibat terkait pula dengan pewartaan kabar sukacita Allah. ${ }^{63}$ Dengan hidup selibat, seorang imam membiarkan dirinya digunakan oleh Allah untuk memberikan diri bagi sesama. Ia menjadi pribadi yang lebih bebas untuk melayani di mana saja, dan kepada siapa saja yang membutuhkan pelayanan sakramental dan pastoral. Selibat memampukan seorang imam untuk semakin terbuka terhadap realitas di luar dirinya. ${ }^{64}$ Ia menjadi pribadi yang terbuka dan siap sedia untuk menjawab berbagai kebutuhan Gereja dan masyarakat di sekitarnya.

Hidup selibat juga menyerukan kepada orang zaman sekarang bahwa ada suatu bentuk kehidupan yang tidak biasa. ${ }^{65}$ Hidup selibat bukan berarti suatu kekurangan dalam menjalani kehidupan di dunia ini, tetapi mengungkapkan suatu kesadaran akan sesuatu yang lebih besar, yang dirindukan oleh semua orang, yakni penantian akan persatuan dengan Kristus yang digambarkan secara megah, meriah, agung, dan penuh kemuliaan. ${ }^{66}$ Seorang imam yang melaksanakan hidup selibat menyerukan kepada dunia mengenai perjamuan utama di surga. Suatu antisipasi atas realitas kehidupan setelah pengalaman di dunia ini, yang dapat dimulai dengan cara hidup para imam yang menghayati selibatnya dengan gembira.
Hidup selibat merupakan suatu pilihan hidup yang mestinya menggembirakan.

\section{HIDUP SELIBAT DALAM BEBERAPA ASPEK KULTUR DI INDONESIA}

Kekayaan makna aspek-aspek teologis dalam hidup selibat perlu dikaitkan dengan beberapa aspek kultur di Indonesia. Kultur merupakan suatu realitas kehidupan yang manusiawi dan setiap imam berasal dari suatu kultur tertentu serta menjadi bagian di dalam kultur tersebut, terutama di Indonesia. Upaya mengaitkan kedua hal tersebut bertujuan agar hidup selibat dapat dipandang sebagai suatu pilihan hidup yang realistis dan manusiawi.

\section{Aspek-Aspek Kultur yang Mendukung Pelaksanaan Hidup Selibat}

Beberapa aspek kultur di Indonesia dapat mendukung pelaksanaan hidup selibat. ${ }^{67}$ Menurut budayawan Jakob Sumardjo, ada beberapa aspek kultur yang dapat mendukung pelaksanaan hidup selibat, yakni sehubungan dengan cara berpikir orang Indonesia yang bersifat "religio-magis". ${ }^{68}$ Cara berpikir yang religius itu nampak dalam beragamnya agama asli di Indonesia. Sebelum masuknya agama-agama besar yang diakui pemerintah Republik Indonesia (Islam, Protestan, Katolik, Hindu, Budha, dan Khong $\mathrm{Hu} \mathrm{Cu}$ ), keyakinan atau sikap religius sudah ada dan bertumbuh di Nusantara dalam bentuk agama-agama asli. ${ }^{69}$ Agama-agama asli tersebut lahir dari pergumulan hidup suatu suku bangsa atau bangsa dalam lingkup hidup tertentu. ${ }^{70}$ Setiap suku bangsa di Indonesia memiliki konsep tentang Yang Ilahi, maka agama asli seringkali disebut sebagai agama suku. Agama tersebut lahir dan hidup dalam proses kehidupan suatu suku bangsa, terutama dalam usaha mereka untuk mengatasi berbagai tantangan kehidupan. ${ }^{71}$

Bukan hanya sisi religius yang ada dalam diri orang Indonesia, tetapi ada pula cara berpikir 'magis'. ${ }^{72}$ Cara berpikir magis itu nampak dalam keyakinan bahwa kehidupan manusia di alam semesta ini tidak pernah lepas dari kekuatan supranatural. Kekuatan supranatural merupakan daya yang melampaui kekuatan pada umumnya. ${ }^{73}$ Masyarakat 
primordial berupaya untuk menyelesaikan berbagai permasalahan hidup mereka dengan cara menghadirkan daya-daya transenden. ${ }^{74}$

Daya-daya transenden tersebut dihadirkan melalui sosok pawang, resi, atau tetua adat $^{75}$ yang telah menjalani hidup spiritual hampir selama hidupnya. ${ }^{76}$ Mereka memperoleh pencerahan spiritual melalui laku reflektif spiritual. ${ }^{77}$ Kehidupan yang diisi dengan laku reflektif spiritual merupakan upaya untuk menjadikan dirinya memiliki kualitas transenden. Tindakan atau laku reflektif spiritual dilakukan dengan cara tidak makan, tidak tidur berhari-hari, bersemedi, dan tidak berhubungan seksual dalam kurun waktu tertentu. ${ }^{78}$

Pelaksanaan hidup spiritual itu juga terdapat dalam citra seorang pinandita ${ }^{79}$ yang memilih untuk hidup wadat atau tidak menikah. ${ }^{80}$ Pilihan hidup untuk tidak menikah tersebut merupakan keputusan pribadi dengan berbagai macam motivasi, yakni pembaktian diri kepada orangtua, saudara, cinta kepada negara, dan cinta terhadap sesama. ${ }^{81}$ Darmawijaya memberikan gambaran mengenai sosok pinandita atau resi dalam beberapa hal berikut: (1) sosok ini memiliki pengalaman rohani yang matang, (2) lepas bebas terhadap hal-hal yang duniawi, (3) dapat mengendalikan nafsu dan diri sendiri, (4) memberikan inspirasi dan menjadi sumber kebijaksanaan bagi sesama, (5) dapat melihat, memahami, dan memberikan makna tentang masa depan, (6) menghendaki keselamatan bagi semua manusia dan dapat mendampingi suatu bangsa. ${ }^{82}$

Cara pandang religio-magis dan gambaran sosok pinandita dapat dikatakan sebagai suatu aspek kultur yang mendukung kehidupan selibat. Apabila dikaitkan dengan hidup selibat, upaya untuk memperoleh kekuatan transenden dengan menjalani hidup spiritual dilaksanakan pula oleh seorang imam dengan hidup selibat. Dalam cara pandang magis, dengan menjalani kehidupan spiritual seseorang dapat menghadirkan daya transenden. Demikian pula dengan hidup selibat yang dilaksanakan oleh para imam. Hidup selibat merupakan tanda dan lambang sekaligus dorongan cinta kasih kegembalaan, serta sumber istimewa bagi kesuburan rohani di dunia. ${ }^{83}$

Daya-daya spiritual yang dipahami masyarakat primordial sebagai daya transenden, dalam pandangan Kristiani dapat dipahami sebagai rahmat sakramental yang diterima oleh umat beriman melalui sakramen-sakramen Gereja. Dalam perayaan sakramen Gereja seorang imam menghadirkan rahmat keselamatan bagi umat Allah, karena dalam sakramen tersebut Kristus hadir dan menyelamatkan umat-Nya. Seorang imam berperan utama sebagai pelayan sakramen. Kekudusan diri seorang imam turut menentukan dalam pelayanan sakramen tersebut. ${ }^{84}$ Pelaksanaan hidup spiritual dalam pandangan magis orang Indonesia selaras dengan panggilan imam untuk hidup dalam kekudusan, karena mereka menjadi sarana yang hidup bagi Kristus, Sang Imam Abadi, yang menghadirkan kekuatan adikodrati demi keselamatan manusia. ${ }^{85}$ Dalam hal ini para imam dapat semakin menyerupai dan membawakan pribadi Kristus, dengan menjadi pinandita, untuk menghadirkan keselamatan bagi umat Allah yang dipercayakan kepadanya. ${ }^{86}$

\section{Aspek-Aspek Kultur yang Menghambat Pelaksanaan Hidup Selibat}

Selain terdapat aspek kultur yang mendukung, ada pula aspek kultur yang menghambat pelaksanaan hidup selibat. Sekurang-kurangnya ada tiga contoh aspek kultur yang dapat melemahkan pelaksanaan dan penghayatan hidup selibat. Contoh yang pertama ialah dalam kepercayaan Agama Djawa Sunda ${ }^{87}$, yang memandang perkawinan sebagai suatu kewajiban. ${ }^{88}$ Kewajiban untuk menikah terkait dengan melaksanakan amanat Tuhan untuk membentuk keluarga dan menghasilkan keturunan. ${ }^{89}$ Contoh yang kedua ialah dalam kepercayaan masyarakat Batak Toba yang memandang bahwa ukuran keberhasilan seseorang ialah mempunyai keturunan laki-laki dan perempuan beserta cucu yang banyak. ${ }^{90}$ Seseorang dikatakan mencapai puncak kebahagiaan hidup jika mempunyai cucu sebagai penerus keturunan, sehingga ia mendapat julukan kehormatan "orang yang bertuah". ${ }^{1}$ 
Dalam arti tertentu, pandangan tentang perkawinan sebagai kewajiban dapat menghambat seseorang memilih menjalani hidup selibat. Hidup perkawinan dan memiliki keturunan seolah-olah menjadi satu-satunya ukuran keberhasilan, kehormatan, dan puncak kebahagiaan. Pandangan yang serupa juga ditemukan di dalam kultur masyarakat Jawa Tengah. Menikah dan memiliki keturunan dipandang sebagai suatu realitas yang alamiah dan menjadi suatu kewajiban hidup. ${ }^{92}$ Apabila seseorang tidak menikah dan tidak memiliki keturunan, ia akan dipandang aneh dan unjavanese (tidak njawani). ${ }^{93}$ Hidup semacam itu dipandang sebagai hidup yang aneh. ${ }^{94}$

Dalam pengertian tertentu, Gereja Katolik juga memandang perkawinan sebagai suatu pilihan hidup yang baik. Allah menghendaki perkawinan antara laki-laki dan perempuan yang diungkapkan dalam persekutuan hidup dan cinta kasih antara suami dan istri. ${ }^{95}$ Hidup perkawinan itu ditujukan untuk meneruskan karya penciptaan yang sudah dimulai oleh Allah. ${ }^{96}$ Hal ini selaras dengan perintah Allah untuk beranakcucu dan bertambah banyak sehingga memenuhi bumi dan dapat memeliharanya. ${ }^{97}$ Perkawinan dimaknai sebagai salah satu pilihan hidup dalam menanggapi panggilan Allah untuk hidup dalam kekudusan. ${ }^{98}$ Ada yang dipanggil untuk hidup dalam kekudusan melalui hidup perkawinan dan ada pula yang dipanggil untuk hidup selibat.

Yohanes Paulus II dalam Familiaris Consortio menyatakan bahwa: "Pernikahan dan selibat merupakan dua jalan masuk ke dalam misteri Allah dalam kehidupan manusia." 99 Dalam hidup perkawinan misteri kehadiran Allah nampak dalam pemberian diri yang setia dan total antara suami-istri serta mengambil bagian dalam karya penciptaan Allah di dunia. Dalam hidup selibat misteri kehadiran Allah nampak dalam diri seorang imam yang mengambil bagian dalam imamat Kristus, sehingga mereka menjadi sarana kehadiran Kristus di dalam dunia.

Hidup perkawinan dan selibat merupakan dua bentuk pilihan hidup yang saling mendukung. Seorang imam dapat mengapresiasi kesetiaan dan komitmen suami- istri untuk saling memberikan diri secara total selama seumur hidup. Dengan menghargai komitmen dalam hidup perkawinan, seorang imam diteguhkan dalam komitmen hidup selibatnya mempersembahkan seluruh hidupnya mengabdi Allah dan melayani Gereja. Demikian pula suami-istri dapat meneladan kesetiaan seorang imam yang mendedikasikan seluruh hidupnya kepada Allah dan mengasihi Gereja.

Hidup selibat menjadi kesaksian akan kasih Allah yang dapat menggerakkan dan mengarahkan seorang imam untuk memberikan diri seutuhnya untuk pelayanan kepada Allah dan sesama. Hidup perkawinan dan selibat dikatakan saling mendukung karena melalui perkawinan terciptalah keluarga Kristiani yang akan menghasilkan keturunan. Anak-anak yang lahir dalam keluarga Kristiani kelak akan dipanggil pula oleh Allah untuk mempertimbangkan pilihan hidup sebagai seorang imam. Demikian pula, seorang imam dipanggil untuk ikut ambil bagian dalam imamat Kristus dan menghadirkan pelayanan Kristus di dalam Gereja-Nya, ${ }^{100}$ termasuk di dalam pelayanan pastoral kepada keluarga, sebagai ecclesia domestica ${ }^{101}$.

Setiap pilihan hidup memiliki keistimewaan sebagai jalan menuju kekudusan. Keistimewaan tersebut tidak menjadikan pilihan hidup yang satu lebih unggul dibanding pilihan hidup yang lain. Keistimewaan itu diungkapkan dalam cara yang khas dari setiap pilihan hidup sebagai panggilan pada kekudusan. Terhadap beberapa aspek kultur di Indonesia yang dapat menghambat pelaksanaan hidup selibat, inspirasi dari Gereja ialah perlunya melihat kedua jalan hidup itu sebagai pilihan yang sama baiknya. Gereja tidak mau memutlakkan salah satu pilihan jalan hidup sebagai yang paling bernilai di atas yang lain.

\section{TAWARAN REINTERPRETASI MAKNA HIDUP SELIBAT IMAM}

Setelah mencermati menggali beberapa aspek-aspek teologis hidup selibat serta mengaitkannya dengan beberapa aspek kultur di Indonesia, ditemukan kekayaan nilai yang terdapat dalam hidup selibat. Kekayaan nilai tersebut menjadikan selibat 
sebagai pilihan hidup yang istimewa. Keistimewaan hidup selibat ditunjukkan dalam cara mencintai, melayani, dan cara hidup. Kekayaan nilai dan keistimewaan hidup selibat menjadikannya sebagai suatu pilihan hidup yang perlu ditawarkan dan diwartakan dalam kehidupan menggereja dan bermasyarakat.

\section{Selibat Sebagai Cara Mencintai}

Hidup selibat bukanlah suatu pilihan hidup untuk berhenti mencinta, tetapi merupakan cara yang radikal dalam mencintai. Cinta yang diungkapkan di sini semata-mata tidak didasari oleh dorongan naluriah seksual yang melihat sesama sebagai objek seksual, tetapi didasari penghargaan atas keutuhan pribadi orang lain yang juga memiliki sisi keilahian di dalam dirinya. Cinta dalam hidup selibat berarti mencintai dengan sepenuh hati seperti Yesus sendiri mencintai sesama, dan sekaligus mencintai Yesus yang ada di dalam diri sesama. ${ }^{102}$

Seorang imam perlu meneladan pribadi Yesus dalam menghidupi seksualitasnya. Dalam kemanusiaan-Nya Yesus merupakan pribadi yang memiliki dorongan seksual sebagaimana dimiliki oleh seorang imam. ${ }^{103}$ Yesus dapat mengintegrasikan dorongan seksual yang ada dalam diri-Nya dan mengungkapkannya dalam sikap yang penuh belas kasih kepada sesama. Sikap yang penuh belas kasih merupakan perwujudan dalam mengintegrasikan dorongan seksualitas yang ada dalam diri manusia. ${ }^{104}$

Yesus merupakan pribadi yang murah hati, lemah-lembut, ramah, hangat, dan penuh kasih kepada sesama-Nya. ${ }^{105}$ Yesus merupakan teladan hidup bagi para imam dalam mengintegrasikan dorongan seksualitas. Yesus mengarahkan ekspresi tubuhNya dalam sikap yang menghendaki keselamatan orang lain. Ia membiarkan diriNya disentuh oleh orang yang ingin disembuhkan. Ia juga menyembuhkan orang sakit dengan sentuhan tangan-Nya. ${ }^{106}$ Ia memandang dengan tatapan penuh kasih yang membuat pendosa bertobat. ${ }^{107}$ Ia pun memiliki kepekaan batin terhadap sesama yang membutuhkan pertolongan-Nya. Seluruh energi dalam diri-Nya disalurkan untuk kehidupan dan keselamatan manusia. ${ }^{108}$

\section{Selibat Sebagai Cara Melayani}

Pelayanan merupakan suatu wujud pemberian diri yang total seorang imam kepada Gereja. Karya pelayanan seorang imam merupakan upaya untuk mengembangkan sisi afektifnya. Sisi afektif tersebut diungkapkan dalam karya pelayanan yang penuh belas kasih kepada Gereja-Nya. Sikap berbelas kasih (compassion) berarti menempatkan diri pada posisi orang lain, turut merasakan penderitaannya seolah-olah menjadi penderitaan sendiri, dan dengan murah hati masuk ke dalam sudut pandangnya. ${ }^{109}$ Henry Nouwen menjelaskan bahwa sikap berbelas kasih berarti keterlibatan penuh dalam situasi yang dialami oleh orang lain. ${ }^{110}$ Belas kasih menuntut kita untuk hadir bersama orang yang menderita, ikut serta dalam ketakutan, kebingungan, dan kecemasan mereka. Seorang imam dipanggil sebagai pelayan umat. Ia dipanggil untuk ikut ambil bagian dalam imamat Kristus dan menghadirkan pelayanan Kristus di dalam Gereja-Nya. ${ }^{111}$

Yesus menyerukan suatu perintah kepada para murid-Nya: "Hendaklah kamu murah hati, sama seperti Bapamu adalah murah hati"(Luk. 6:36). Perintah tersebut merupakan ajakan untuk turut ambil bagian dalam belas kasih Allah kepada manusia yang dihadirkan oleh Yesus di dunia ini. Dengan rahmat tahbisan yang diterima, seorang imam mengambil bagian dalam imamat Kristus yang pada dasarnya ditujukan pada pelayanan umat Allah. ${ }^{112}$

Imam dipanggil untuk menjadi pelayan umat dalam berbagai macam karya pelayanan, seperti bertugas sebagai pastor di paroki, di dalam karya-karya kategorial gerejawi, karya pendidikan, dan sebagainya. ${ }^{113}$ Dalam berbagai karya pelayanan itulah seorang imam hadir dan melayani umat yang dipercayakan kepadanya. Selain itu, dalam berbagai karya pelayanan tersebut, secara tidak langsung seorang imam juga memberikan kesaksian kepada masyarakat yang ada di sekitar wilayah pelayanannya. Aspek kesaksian ini selaras dengan yang dikatakan oleh Paus Fansiskus dalam anjuran apostolik Evangelii Gaudium, yakni Gereja yang pergi keluar. ${ }^{114}$ Gereja didorong untuk pergi keluar dan memberi, keluar dari diri sendiri 
dan mewartakan Kabar Gembira ke seluruh dunia. ${ }^{115}$ Gereja diajak untuk keluar dan mencari serta menjumpai mereka yang tersesat dan tersingkir. ${ }^{116}$

Para imam diajak untuk menjadi gembala yang "berbau domba". ${ }^{117}$ Menurut Paus Fransiskus, gembala yang berbau domba ialah: ${ }^{118}$ (1) yang mau datang dan terlibat dalam kehidupan umat sehari-hari, (2) yang mau menopang dan mendampingi umat dalam setiap langkah perjalanan hidup mereka, (3) bahkan yang bersedia mempertaruhkan seluruh kehidupannya untuk keselamatan domba-domba-Nya.

Di sini ditemukan keistimewaan lain dari hidup selibat imam yaitu sebagai suatu cara melayani. Seorang imam mengupayakan kesucian dirinya agar layak turut serta dalam tugas yang diemban untuk menghadirkan Kristus dan menjadi sarana dalam karya penyelamatan manusia. ${ }^{119}$ Komitmen untuk hidup selibat berarti kesediaan membiarkan diri digunakan oleh Allah demi kepentingan sesama. Seorang imam adalah pribadi yang terbuka untuk menanggapi berbagai kebutuhan Gereja.

\section{Suatu Pilihan Hidup Spiritual}

Selibat merupakan suatu pilihan hidup spiritual. Hidup selibat harus didasari oleh motivasi spiritual, yakni supaya lebih bersatu dengan Kristus, memberikan seluruh hidup kepada Kristus dan mengambil bagian dalam karya pelayanan Kristus demi Kerajaan Allah. ${ }^{120}$ Hidup selibat adalah pilihan bebas seseorang menanggapi panggilan Allah untuk mendedikasikan seluruh hidupnya kepada sesama. Motivasi untuk hidup selibat merupakan suatu motivasi yang bersifat spiritual. Motivasi tersebut selaras dengan panggilan Allah kepada seorang imam untuk hidup dalam kekudusan sebagaimana Kristus dikuduskan oleh Bapa untuk menyucikan manusia. ${ }^{121}$ Seorang imam melalui pengurapan Roh Kudus dipanggil untuk melaksanakan tugas menguduskan Gereja yang diwujudkan dalam karya pelayanan sakramental yang menghadirkan kekuatan adikodrati untuk keselamatan manusia. ${ }^{122}$ Kekudusan diri merupakan suatu bentuk keterbukaan diri seorang imam agar rahmat Allah dapat dihadirkan dalam kehidupan manusia. Kekudusan diri seorang imam sangat berarti dalam melaksanakan peranannya sebagai perantara rahmat keselamatan Allah kepada manusia. Khususnya dalam Perayaan Ekaristi, seorang imam menghadirkan pribadi Kristus yang telah menyerahkan diri sebagai korban untuk pengudusan manusia. ${ }^{123}$

Dalam melaksanakan pelayanan sakramental tersebut, seorang imam dipanggil untuk menjaga kekudusan dirinya dengan cara mematikan perbuatan daging yang diwujudkan dalam hidup selibat. Upaya menjaga kekudusan diri merupakan proses mentransendensikan diri agar semakin menyerupai Yesus Kristus perantara antara Allah dan manusia. Transendensi diri dapat dimaknai sebagai upaya manusia untuk mengatasi kecenderungan manusiawi dengan cara pengingkaran diri agar rahmat Allah dapat memperlengkapi dirinya. Kecenderungan manusiawi yang dalam kodrat manusia diperkaya dengan rahmat Allah yang bekerja dalam diri manusia dengan tetap menghormati kebebasan manusia. ${ }^{124}$

Seorang imam dipanggil untuk menghayati kehidupan yang adikodrati agar dapat mengabdi. Ia terus berusaha untuk mengatasi kecenderungan manusiawinya dengan memohon rahmat Allah. Seorang imam dipanggil untuk menjadi sarana yang hidup bagi Kristus, Sang Imam Abadi, agar dapat melangsungkan karya penyelamatan-Nya di dunia. $^{125}$ Seseorang yang memilih hidup selibat perlu mengembangkan sisi spiritual dalam dirinya, yakni dengan cara menekuni hidup doa dan melaksanakan askese. Hidup doa menjadi unsur yang esensial dalam menghayati pilihan hidup selibat. Dalam hidup doanya seorang imam semakin mendekatkan dirinya kepada pribadi Kristus sebagai teladan utama dalam melaksanakan hidup selibat. Dengan menerima kekuatan dan sukacita dalam menghayati hidup selibatnya $^{126}$, ia semakin diteguhkan bahwa hidup selibat merupakan suatu pilihan hidup yang berarti bagi Gereja dan dunia. Melalui hidup doa seorang imam dapat menimba kekuatan rohani dan memohon rahmat Allah untuk mengintegrasikan dorongan seksualitasnya dalam upaya memberikan dirinya sepenuhnya kepada kehendak Allah. 
Salah satu upaya transendensi diri adalah dengan melaksanakan askese. Askese merupakan suatu bentuk disiplin diri dan suatu proses pemurnian diri, ${ }^{127}$ sehingga seorang imam semakin menyadari kelemahan dan kencenderungan manusiawinya. Berhadapan dengan keterbatasan dirinya, seorang imam dapat lebih berhati-hati agar tidak terjebak dalam godaan yang dapat membahayakan hidup selibat. Selanjutnya, ia memohonkan rahmat Allah untuk mengatasi keterbatasannya agar ia dapat bertumbuh dalam kekudusan dan menjadi sarana kehadiran Kristus di dunia.

Hidup doa dan askese merupakan upaya yang esensial untuk dapat menghayati hidup selibat. Hidup selibat merupakan tindakan spiritual untuk menghadirkan rahmat sakramental bagi keselamatan umat Allah. Dalam pilihan hidup spiritual ini, seorang imam membaktikan seluruh hidupnya bersama dan dalam Kristus untuk melaksanakan suatu karya pelayanan demi keselamatan jiwa-jiwa yang dipercayakan Allah kepadanya.

\section{Selibat Sebagai Suatu Peziarahan}

Selibat adalah suatu proses, yang berlangsung semenjak seseorang berkomitmen untuk hidup selibat sampai dengan akhir hidupnya. Sakramen tahbisan yang diterima oleh seorang imam mungkin tidak langsung menjadi jaminan bahwa ia dapat dengan setia dan tanpa hambatan menjalani hidup selibatnya, tetapi merupakan titik awal dari proses untuk menghayati selibat. Selanjutnya, dibutuhkan kesetiaan dan perjuangan seumur hidup agar seorang imam dapat menghayati anugerah selibat. Karl Rahner, sebagaimana dikutip oleh Ridick, menjelaskan mengenai rahmat, kesetiaan, dan perjuangan untuk melaksanakan hidup selibat.

\footnotetext{
"Sebagaimana dorongan seksual belum menjadi ungkapan cinta sebelum terarah dalam kesetiaan yang disertai pergulatan dan jerih lelah, begitu pula rahmat belum nyata menjadi rahmat dalam diri kita sebelum dihayati dengan kesetiaan yang disertai pergulatan dan jerih lelah. Seseorang tetap setia karena ditarik oleh panggilan hidup abadi dan cinta Allah, suatu panggilan untuk mewartakan dan sekaligus memanggul salib Kristus. Ini bukan hanya
}

teori semata, melainkan harus benarbenar diwujudkan dalam hidup dan disertai pergulatan serta jerih payah."128

Kesetiaan yang disertai dengan pergulatan dan jerih lelah perlu diupayakan oleh seorang imam dalam menghayati hidup selibatnya. Kesetiaan itu diwujudkan dalam mengintegrasikan dorongan seksualnya menjadi ungkapan cinta, kemampuan menjalin persahabatan dan persaudaraan yang berarti, serta kreativitas untuk memaknai kesendiriannya. Pergulatan dan jerih lelah akan mewarnai perjuangan seorang imam untuk setia menghayati hidup selibatnya. Perjuangan membutuhkan pertolongan rahmat dari Allah yang akan senantiasa menguatkan kesetiaannya menanggapi panggilan hidup selibat. Keterkaitan antara rahmat Allah dan kesetiaan yang disertai pergulatan dan jerih lelah merupakan bagian proses melaksanakan dan menghayati hidup selibat.

Proses menghayati hidup selibat dapat dikaitkan dengan proses peziarahan. Ign. Suharyo mengatakan bahwa bersyukur, berharap, dan membuat niat pribadi merupakan unsur-unsur terpenting dalam peziarahan. ${ }^{129}$ Peziarahan merupakan suatu proses perjalanan menuju suatu tujuan. Dalam proses mencapai tujuan itu terkandung suatu ungkapan syukur yang disertai dengan harapan dan didorong oleh suatu niat pribadi. Ketiga unsur itu terdapat dalam proses menghayati hidup selibat, sebagaimana dijelaskan sebagai berikut:

a. Seorang imam pertama-tama perlu mensyukuri anugerah selibat yang diterimanya dari Allah. Selibat merupakan suatu panggilan "khusus" untuk hidup dalam kekudusan. ${ }^{130}$ Dikatakan sebagai panggilan khusus, karena merupakan suatu panggilan untuk menjadi sarana yang hidup guna menghadirkan Pribadi Kristus sendiri bagi umat Allah yang dipercayakan kepada seorang imam. ${ }^{131}$ Seseorang yang menerima panggilan itu patut mensyukurinya sebagai karunia dari Allah.

b. Panggilan hidup itu terkait dengan amanat yang disampaikan oleh Kristus: "Hendaklah kalian menjadi sempurna, seperti Bapamu di sorga adalah sempur- 
na” (Mat. 5:48). Seorang imam dipanggil untuk menuju kekudusan diri, meskipun ia tetap memiliki keterbatasan manusiawi. ${ }^{132}$ Berhadapan dengan tegangan antara keterbatasan diri dan panggilan menuju kekudusan itu, seorang imam membutuhkan rahmat Allah untuk menopang kelemahan manusiawinya. Ia mengharapkan rahmat dari Allah agar dapat mempersembahkan diri seutuhnya dalam mengabdi Allah dan sesama.

c. Dalam keterbatasan dirinya, bukan tidak mungkin bahwa seorang imam jatuh dan mengalami kegagalan dalam menghayati hidup selibatnya. Harapan akan pengampunan dan belas kasih Allah merupakan suatu kekuatan yang kembali meneguhkannya sehingga ia dapat bangkit kembali. Rahmat pengampunan dan pertolongan dari Allah akan menumbuhkan keyakinan dan niat pribadi dalam dirinya untuk memperbaiki kekeliruannya dan melanjutkan perjalanannya kembali.

Cara mencintai, cara melayani, dan cara hidup merupakan tiga tawaran reintepretasi makna hidup selibat sebagai suatu kesaksian. Ketiga cara tersebut merupakan suatu tawaran yang perlu diusahakan dan dihidupi secara terus-menerus agar selibat menjadi kesaksian hidup yang berarti bagi Gereja dan tidak menutup kemungkinan menjadi kesaksian pula bagi masyarakat yang ada di sekitarnya.

\section{PENUTUP}

Selibat sebagai kesaksian hidup merupakan suatu tanggapan atas pandangan bahwa selibat (khususnya selibat imam) bukanlah suatu pilihan hidup yang mudah untuk dijalani. Adanya anggapan tersebut bisa saja karena dipengaruhi oleh terungkapnya kasus pelecehan seksual oleh kaum imam di

\section{CATATAN AKHIR}

1 Dokumentasi dan Penerangan KWI. "Presbyterorum Ordinis: Hidup dan Pelayanan Imam" dalam Dokumen Konsili Vatikan II (Jakarta: Obor, 1993), 509. untuk selanjutnya disingkat $P O$.

2 Lih. Edison R.L. Tinambunan, Spiritualitas Imamat, sebuah pendasaran (Malang: Dioma, beberapa negara, pandangan budaya yang melihat hidup selibat itu tidak lazim, serta situasi zaman yang cenderung merendahkan makna seksualitas.

Selibat merupakan kesaksian hidup yang mewartakan tentang totalitas pengabdian diri kepada Allah dan sesama. Totalitas tersebut adalah pesan yang menjadikan selibat adalah pilihan hidup yang berharga dan bermakna. Kesaksian mengenai hidup selibat akan semakin menginspirasi umat beriman, jika para imam menghayatinya dengan gembira. Selibat merupakan pilihan hidup yang membahagiakan untuk mencintai dan mengabdi Allah melalui pelayanan yang total kepada sesama. Dengan melihat kebahagiaan seorang imam dalam melaksanakan hidup selibat, umat beriman terpanggil untuk mendukung hidup selibat, meskipun dibutuhkan kesetiaan dan perjuangan untuk menjalaninya.

Kekayaan makna hidup selibat tersebut kemudian diartikulasikan kembali untuk menampilkan keistimewaannya terutama ketika berhadapan dengan situasi zaman yang kadang-kadang kurang mendukung pilihan hidup tersebut. Keistimewaan hidup selibat saya tunjukkan dengan tiga tawaran reinterpretasi maknanya di zaman ini, yakni sebagai cara mencintai, cara melayani, dan cara hidup. Reinterpretasi ini menyingkapkan bahwa hidup selibat tetap merupakan jalan hidup yang unik dan berharga ketika berhadapan dengan perubahan zaman.

\section{Yohanes Hario Kristo Wibowo}

Mahasiswa Program Pascasarjana -
Program Magister Ilmu Teologi
Universitas Katolik Parahyangan,
Bandung. Jl. Nias 2, Bandung 40117.
Email: kristohario90@gmail.com

2006), 10-11. Ia mengutip dari Stephen Pope, Accountability and Sexual Abuse in The United States: Lessons for the universal church, dalam Irish Theological Quarterly, U. 69, No.1 (2004), 73-74.

3 Hidup, Edisi No. 38, 21 September 2014, 1.

4 Bdk. PO, 507.

5 Lih. Hidup, 12. 
6 "Paus Fransiskus mengecam imam pelaku kekerasan seksual. Kasus seksual yang melibatkan imam, sesekali menyembul ke publik. Benarkah "selibat" menjadi akar persoalan ini? Panggilan hidup selibat sebaiknya menjadi pilihan bebas atau salah satu elemen wajib?" Lih. Hidup, 4.

7 Kongregasi untuk Klerus, Direktorium tentang Pelayanan dan Hidup Para Imam (Jakarta: Dokpen KWI, 1996), art. 60.

8 Bdk. Diarmuid O'Murchu, Poverty, Celibacy, and Obedience (New York: A Crossroad Book, 1999), 52.

9 Bdk. Dominikus Gusti Bagus Kusumawanta, Imam di Ambang Batas (Yogyakarta: Kanisius, 2009), 58.

10 Bdk. Niko Hayon, Cinta yang Mengabdi (Ende: Nusa Indah, 1989), 10-11.

11 Lih. Jugenkatechismus der Katholishen Kirche. YOUCAT Deutsch (Munich: Pattloch Verlag \& Co, Kg, 2010), Yohanes Dwi Harsanto, dkk. (terj) YOUCAT Indonesia, Katekismus Populer. (Yogyakarta: Kanisius, 2012), 152; untuk selanjutnya disingkat YOUCAT.

12 Lih. A. Heuken, Ensiklopedi Gereja (Jakarta: Yayasan Cipta Loka Caraka, 1994), 191.

13 Para Waligereja Regio Nusa Tenggara, Katekismus Gereja Katolik (Ende: Arnoldus Ende, 1995), art. 1579; untuk selanjutnya disingkat $K G K$.

14 Bdk. Heuken, Ensiklopedi, 191.

15 Bdk. A. W. Richard Sipe, Celibacy in Crisis (New York and hove: Brunner-Routledge, 2003), 32.

16 Lih. Th. Maman Suharman,. "Menggali Makna Imamat, Doa, dan Selibat Kristiani" dalam Melintas Volume 28, No. 03 (Desember 2012), (Bandung: Fakultas Filsafat, Universitas Katolik Parahyangan), 333.

17 Konferensi Waligereja Indonesia, Kitab Hukum Kanonik (Bogor: Grafika Mardi Yuana, 2016) kan. 277; untuk selanjutnya disingkat $K H K$.

18 Lih. Bagus Irawan, Seks, Selibat, \& Persahabatan sebagai Karisma (Jakarta: Obor, 2009), 26.

19 Bdk. O'Murchu, Poverty, Celibacy, and Obedience, 52.

20 Bdk. Roderick Strange, The Risk of Discipleship, Imamat Bukan Sekadar Selibat (Yogyakarta: Kanisius, 2007), 173.

21 Bdk. Irawan, Seks, 52.
22 Lih. Wolfgang Beinert and Francis ShÜssler Fiorenza (ed), Handbook of Catholic Theology (New York: The Crossroad Publishing Company, 1995), 57.

23 Sipe, Celibacy in Crisis, 32.

24 Lih. Mat. 19:11-12.

25 Lih. Crescenzio Sepe, Titular Archbishop of Grado, Secretary of the Congregation for the Clergy dalam "The Relevance of Priestly Celibacy Today".

http://www.vatican.va/roman_curia/congrega tions/cclergy/documents/rc_con_cclergy_doc _01011993_revel_en.html; (akses pada 18 Agustus 2017).

${ }^{26}$ Lih. Paulus VI. Sacerdotalis Caelibatus: Encyclical of Pope Paul VI on The Celibacy of The Priest, 1967, art. 19. Untuk selanjutnya disingkat Caelibatus.

27 Ibid.: "Christ, the only Son of the Father, by the power of the Incarnation itself was made Mediator betweeen heaven and earth, between the Father and the human race. Wholly in accord with this mission, Christ remained throughout His whole life in the state of celibacy, which signified His total dedication to the service of God and men."

28 Lih. Sepe, "The Relevance of Priestly Celibacy Today".

29 Lih. Caelibatus, art. 26.

30 Yohanes Paulus II, Anjuran Apostolik Pastores Dabo Vobis. Terj. R. Hardawirjana. (Jakarta: Departemen Dokumentasi dan Penerangan KWI, 1992), art. 29. Untuk selanjutnya disingkat: $P D V$.

31 Lih. Caelibatus, art. 26: "The consecrated celibacy of the sacred ministers actually manifests the virginal love of Christ for the Church, and the virginal and supernatural fecundity of this marriage, by which the children of God are born, "not of blood, nor of the will of the flesh'."

32 Caelibatus, art. 27.

33 Caelibatus, art. 28.

34 Lih. E. Martasudjita, Sakramen-sakramen Gereja (Yogyakarta: Kanisius, 2003), 288.

35 Lih. Caelibatus, art. 29.

36 Caelibatus, art. 32.

37 Caelibatus, art. 32.

38 Lih. $P D V$, art. 50.

39 Lih. Direktorium tentang Pelayanan dan Hidup Para Imam, art. 57.

40 Luk. 20:34-36.

41 Lih. $P O, 508$.

42 Lih. Caelibatus, art. 34.

${ }^{43}$ Lih. Flp. 2:8-9. 
44 Lih. Sandra M. Schneiders, Selling All: Commitmen, Consecrated Celibacy, and Community in Catholic Religious Life (New Jersey: Paulist Press, 2001), 117.

45 Lih. $P D V$, art. 29.

46 Lih. Irawan, Seks, 52.

47 Lih. Schneiders, Selling All, 118.

48 Lih. Agnes Sheehan, "Charismatic and Prophetic Roles" dalam Consecrated celibacy (Canada: Canadian Religious Conference, 1971), 12.

49 Bdk. PO, 481.

50 Lih. Schneiders, Selling All, 117.

51 Lih. Heuken, Ensiklopedi, 194.

52 Lih. Crescenzio Sepe, "The Relevance of Priestly Celibacy Today".

53 Lih. Heuken, Ensiklopedi, 194.

54 Lih. Heuken, Ensiklopedi, 194.

55 Bdk. O'Murchu, Poverty, Celibacy, and Obedience, 52.

56 Bdk. Joyce Ridick, Treasures in Earthen Vessels: The Vows (New York: Alba House, 1984), F. Mardi Prasetyo, dkk (terj), Kaul: Harta Melimpah dalam Bejana Tanah Liat (Yogyakarta: Kanisius, 1987), 101.

57 Bdk. Donald Goergen, The Sexual Celibate (New York: The Seabury Press, 1974), 116.

58 Lih. Paul Suparno, Seksualitas Kaum Berjubah (Yogyakarta: Kanisius, 2007), 88.

59 Lih. Direktorium tentang Pelayanan dan Hidup Para Imam, art. 60.

60 Lih. Goergen, Sexual, 129.

61 Lih. $P O, 512$.

62 Bdk. Ridick, Kaul, ,84.

63 Lih. Paulus Budi Kleden, Aku yang Solider, Aku dalam Hidup Berkaul (Maumere-Flores: Penerbit Ledalero, 2002), 97.

64 Lih. Irawan, Seks, 52; tekanan dari saya.

65 Lih. Kleden, Aku yang Solider, 82.

66 Lih. Caelibatus, art. 33.

67 Berdasarkan wawancara dengan Jakob Sumardjo, Guru Besar Sekolah Tinggi Seni Indonesia (STSI) Bandung, pada Kamis, 26 Maret 2015.

68 Lih. Jakob Sumardjo, Estetika Paradoks (Bandung: Penerbit Kelir, 2014), 9-10:

"Cara berpikir religio-magis ialah upaya untuk memecahkan masalah-masalah hidup yang ada di luar kemampuan manusia melalui ritual untuk menghadirkan daya-daya abstrak transenden. Perubahan manusia dan dunia terjadi karena campur tangan daya-daya transenden di luar manusia dan alam raya ini."

69 Lih. A. Eddy Kristiyanto, "Pengantar" dalam A. Eddy Kristiyanto (ed), Spiritualitas
Dialog-Narasi Teologis tentang Kearifan Religius (Yogyakarta:Kanisius, 2010), 11.

70 Lih. Julius Salettia, "Beberapa Keyakinan Keagamaan Asli Minahasa" dalam Spiritualitas Dialog-Narasi Teologis tentang Kearifan Religius (Yogyakarta: Kanisius, 2010), 89.

71 Julius Salettia, "Beberapa Keyakinan Keagamaan Asli Minahasa", 89.

72 Lih. Sumardjo, Estetika, 11:

"Cara berpikir magis ialah upaya untuk memperoleh pengetahuan yang terkait dengan praktik kehidupan, entah untuk memperoleh kekayaan atau kekuasaan di dunia ini, untuk memahami dirinya sendiri, memperoleh informasi tentang hidup, kematian, dan tentang cara mencari dan menemukan Tuhan."

73 Lih. Kristiyanto (ed), Spiritualitas Dialog, 15.

74 Lih. Sumardjo, Estetika, 10.

75 Lih. Sumardjo, Estetika, 173:

"Dalam kerajaan Sunda, Resi ialah semacam raja pendeta yang kebanyakan sudah lanjut usia, banyak merenung dan laku tapa, menulis ajaran-ajaran yang menjadi hukum etik negara, dan bertempat tinggal di istana yang jauh dari dua lembaga kerajaan yang lain, yakni Ratu dan Rama."

76 Lih. Sumardjo, Estetika., 7.

77 Lih. Sumardjo, Estetika, 10.

78 Lih. Sumardjo, Estetika, 38.

79 Lih. St. Darmawijaya, Citra Imam-Satriya Pinandita (Yogyakarta: Kanisius, 1991), 25:

"Pinandita ialah sosok yang mempunyai peranan dalam masyarakat. Ia berperan sebagai kekuatan moral-spiritual dengan terlibat membangun lingkungan dan tampil sebagai saksi manusia utuh, Seorang pinandita menjadi gambaran orang yang sudah sampai pada kepenuhannya, dan mampu mengabdikan kepenuhan itu bagi sesama."

80 St. Darmawijaya, Citra Imam-Satriya Pinandita, 22.

81 Lih. St. Darmawijaya, Hidup Murni (Yogyakarta: Kanisius, 1987), 33.

82 St. Darmawijaya, Hidup Murni, 25.

83 Lih. $P O, 507$.

${ }^{84}$ Lih. $P O, 481$.

85 Lih. $P O, 481$.

86 Lih. $P O, 481$.

87 Lih. Eddy Putranto, dkk, Semakin Mandiri untuk Menjadi Ragi: Seri kedua 80 Tahun Keuskupan Bandung (Bandung: Panitia 80 Tahun Keuskupan Bandung, 2012), 111-112. 
Ibid., 197.

90 Lih. Herman Togar Nainggolan, "Fenomena Imam Batak Toba: Tinjauan Antropologis tentang Keberadaan dan Fungsi Mereka", dalam Spiritualitas Dialog-Narasi Teologis tentang Kearifan Religius (Yogyakarta: Kanisius, 2010), 123.

91 Herman Togar Nainggolan, "Fenomena Imam Batak Toba: Tinjauan Antropologis tentang Keberadaan dan Fungsi Mereka", 123.

92 Lih. Niels Mulder, Individual and Society in Java: A Cultura; Analysis (Yogyakarta: Gadjah Mada University Press, 1992), 24.

93 Lih. Mulder, Individual and Society, 24.

94 Lih. Mulder, Individual and Society, 24.

95 Lih. Para Waligereja, Katekismus, no. 1603.

96 Lih. Caelibatus, art. 20.

97 Lih. Kej. 1:28.

98 Konferensi Waligereja Indonesia, Kompendium Katekismus Gereja Katolik (Yogyakarta: Kanisius, 2009), no. 342.

99 Bdk. Paul John II, "Familiaris Consortio: Encyclical the Christian Family in the Modern Word" dalam Acta Apostolicae Sedis, (Rome: Commentarium Officiale, 1981), 73.

${ }^{100}$ Lih. Edison, Spiritualitas, 43.

${ }^{101}$ Lih. Benedictus XVI, Bapa-Bapa Gereja: Hidup Ajaran dan Relevansi bagi Manusia di Zaman Kini, (Malang: Dioma, 2010), 135149.

102 Lih. Ridick, Kaul, 87.

${ }^{103}$ Lih. Goergen, Sexual, 26.

${ }^{104}$ Lih. Goergen, Sexual, 26.

${ }^{105}$ Lih. Goergen, Sexual, 26.

${ }^{106}$ Bdk. Suparno, Seksualitas, 138.

107 Bdk. Suparno, Seksualitas, 138.

${ }^{108}$ Bdk. Suparno, Seksualitas, 138.

${ }^{109}$ Lih. Karen Amstrong, The Twelve Steps to a Compassion Life (Canada: Alfred A. Knopf, 2010), Yuliani Lipiro (terj.), Compassion: 12 Langkah Menuju Hidup Berbelas Kasih (Bandung: PT Mizan Pustaka, 2012), 15.

${ }^{110}$ Lih. Henry J. M. Nouwen, A Reflection on the Christian life (London: Douglas A. Morrison, Darton, Longman and Todd Ltd, 1982), I. Suharyo, dkk (terj.), Sehati Seperasan: Sebuah Permenungan Tentang Hidup Kristen (Yogyakarta: Kanisius, 1987), 16.

${ }^{111}$ Lih. Edison, Spiritualitas, 43.

${ }^{112}$ Lih. Edison, Spiritualitas, 45.

${ }^{113}$ Lih. Edison, Spiritualitas, 45.

${ }^{114}$ Lih. Paus Fransiskus, Evangelii Gaudium, R.F. Bhanu Viktorahadi (terj.), Sukacita Injil:
Surat Anjuran Bapa Suci Paus Fransiskus tentang Pewartaan Injil di Dunia Dewasa ini (Yogyakarta: Kanisius, 2015), art. 20.

115 Paus Fransiskus, Evangelii Gaudium, art. 21.

${ }^{116}$ Paus Fransiskus, Evangelii Gaudium, art. 24.

117 Paus Fransiskus, Evangelii Gaudium, art. 24.

118 Paus Fransiskus, Evangelii Gaudium, art. 24.

${ }^{119}$ Lih. Edison, Spiritualitas, 49.

${ }^{120}$ Lih. Goergen, Sexual, 112.

${ }^{121}$ Lih. $P O, 498$.

${ }^{122}$ Lih. $P O, 498$.

${ }^{123}$ Lih. $P O, 501$.

${ }^{124}$ Bdk. Ridick, Kaul, 85.

${ }^{125}$ Lih. PO, 501.

${ }^{126}$ Bdk. Caelibatus, art. 74.

${ }^{127}$ Lih. Goergen, Sexual, 216.

${ }^{128}$ Ridick, Kaul, 105. Kutipan tersebut mengacu kepada tulisan Karl Rahner, Lettera Aperta Sul Celibato (Brescia: Queriniana, 1697), 31.

${ }^{129}$ Lih. Ignatius Suharyo, "Gereja yang Berbelarasa" dalam Menjadi Gereja yang Berbelarasa: Inspirasi Kasih Mgr. Ignatius Suharyo bagi Umat Keuskupan Bandung (Bandung: Dewan Karya Pastoral Keuskupan Bandung, 2014), 88.

${ }^{130}$ Lih. $P D V$, art. 20.

${ }^{131}$ Lih. $P D V$, art. 20.

${ }^{132}$ Lih. $P O, 507$.

\section{DAFTAR RUJUKAN}

\section{Dokumen Gereja:}

Dokumentasi dan Penerangan KWI. "Presbyterorum Ordinis: Tentang Pelayanan dan Kehidupan Para Imam" dalam Dokumen Konsili Vatikan II. Jakarta: Obor, 1993.

Kongregasi untuk Klerus. Direktorium tentang Pelayanan dan Hidup Para Imam. Diterjemahkan oleh: R. Hardawirjana. Jakarta: Departemen Dokumentasi dan Penerangan KWI, 1996.

Paulus VI. Sacerdotalis Caelibatus: Encyclical of Pope Paul VI on The Celibacy of The Priest. 1967. 
Paus Fransiskus. Evangelii Gaudium. Diterjemahkan oleh: R.F. Bhanu Viktorahadi. Sukacita Injil: Surat Anjuran Bapa Suci Paus Fransiskus tentang Pewartaan Injil di Dunia Dewasa ini. Yogyakarta: Kanisius, 2015.

Paul John II, "Familiaris Consortio: Encyclical the Christian Family in the Modern Word" dalam Acta Apostolicae Sedis. Rome: Commentarium Officiale, 1981.

Yohanes Paulus II, Anjuran Apostolik Pastores Dabo Vobis. Diterjemahkan oleh: R. Hardawirjana. Jakarta: Departemen Dokumentasi dan Penerangan KWI, 1992.

\section{Pustaka Pendukung:}

Amstrong, Karen. The Twelve Steps to a Compassion Life. Canada: Alfred A. Knopf, 2010. Diterjemahkan oleh: Yuliani Lipiro. Compassion: 12 Langkah Menuju Hidup Berbelas Kasih. Bandung: PT Mizan Pustaka, 2012.

Benedictus XVI, Bapa-Bapa Gereja: Hidup Ajaran dan Relevansi bagi Manusia di Zaman Kini. Malang: Dioma, 2010.

Budi Kleden, Paulus. Aku yang Solider, Aku dalam Hidup Berkaul. MaumereFlores: Penerbit Ledalero, 2002.

Darmawijaya, St. Citra Imam-Satriya Pinandita. Yogyakarta: Kanisius, 1991.

\section{, Hidup Murni. Yogyakarta: Kanisius, 1987.}

Donald Goergen, The Sexual Celibate. New York: The Seabury Press, 1974.

Hayon, Niko. Cinta yang Mengabdi. Ende: Nusa Indah, 1989.

Irawan, Bagus Al. Seks, Selibat, $\mathcal{E}$ Persahabatan sebagai Karisma. Jakarta: Obor, 2009.
Kristiyanto, A. Eddy (ed). Spiritualitas Dialog-Narasi Teologis tentang Kearifan Religius. Yogyakarta: Kanisius, 2010.

Kusumawanta, Dominikus Gusti Bagus. Imam di Ambang Batas. Yogyakarta: Kanisius, 2009.

Martasudjita, E. Sakramen-sakramen Gereja. Yogyakarta: Kanisius, 2003.

Mulder, Niels. Individual and Society in Java: A Cultura; Analysis. Yogyakarta: Gadjah Mada University Press, 1992.

Nouwen, Henry J.M. A Reflection on the Christian life. London: Douglas A. Morrison, Darton, Longman and Todd Ltd, 1982. Diterjemahkan oleh:. I. Suharyo, dkk. Sehati Seperasan: Sebuah Permenungan Tentang Hidup Kristen. Yogyakarta: Kanisius, 1987.

O'Murchu, Diarmuid. Poverty, Celibacy, and Obedience. New York: A Crossroad Book, 1999.

Putranto, Eddy dkk, Semakin Mandiri untuk Menjadi Ragi: Seri kedua 80 Tahun Keuskupan Bandung. Bandung: Panitia 80 Tahun Keuskupan Bandung, 2012.

Ridick, Joyce. Treasures in Earthen Vessels: The Vows (New York: Alba House, 1984), F. Mardi Prasetyo, dkk (penerjemah), Kaul: Harta Melimpah dalam Bejana Tanah Liat (Yogyakarta: Kanisius, 1987.

Sipe, Richard A.W. Celibacy in Crisis. New York and Hove: Brunnes Routledge, 2003.

Schneiders, Sandra M. Selling All: Commitmen, Consecrated Celibacy, and Community in Catholic Religious Life. New Jersey: Paulist Press, 2001.

Sheehan, Agnes. "Charismatic and Prophetic Roles" dalam Consecrated celibacy. Canada: Canadian Religious Conference, 1971. 
Strange, Roderick. The Risk of Discipleship, Imamat Bukan Sekadar Selibat. Yogyakarta: Kanisius, 2007.

Sumardjo, Jakob. Estetika Paradoks. Bandung: Penerbit Kelir, 2014.

Suharyo, Ignatius. "Gereja yang Berbelarasa" dalam Menjadi Gereja yang Berbelarasa: Inspirasi Kasih Mgr. Ignatius Suharyo bagi Umat Keuskupan Bandung. Bandung: Dewan Karya Pastoral Keuskupan Bandung, 2014.

Suparno, Paul. Seksualitas Kaum Berjubah. Yogyakarta: Kanisius, 2007.

Tinambunan, Edison R. L. Spiritualitas Imamat. Malang: Penerbit Dioma, 2004.

\section{Jurnal:}

Suharman, Maman Th. "Menggali Makna Imamat, Doa, dan Selibat Kristiani" dalam Melintas Volume 28, No. 03 (Desember 2012). Bandung: Fakultas Filsafat, Universitas Katolik Parahyangan.

\section{Majalah:}

Majalah Mingguan Katolik, Hidup, Edisi No. 38 (21 September 2014). Jakarta: PT Gramedia.

\section{Referensi:}

Heuken, Adolf. Ensiklopedi Gereja. Jakarta: Yayasan Cipta Loka Caraka, 1994

Jugenkatechismus der Katholishen Kirche. YOUCAT Deutsch. Munich: Pattloch Verlag \& Co, Kg, 2010. Diterjemahkan oleh: Yohanes Dwi Harsanto, dkk. YOUCAT Indonesia, Katekismus Populer. Yogyakarta: Kanisius, 2012.

Konferensi Waligereja Indonesia, Kompendium Katekismus Gereja Katolik. Yogyakarta: Kanisius, 2009. , Kitab Hukum Kanonik: Edisi Resmi Bahasa Indonesia (Revisi II). Bogor: Percetakan Grafika Mardi Yuana, 2016.

Para Waligereja Regio Nusa Tenggara, Katekismus Gereja Katolik. Ende: Arnoldus Ende, 1995.

Wolfgang Beinert and Francis ShÜssler Fiorenza (ed), Handbook of Catholic Theology. New York: The Crossroad Publishing Company, 1995. 
